\title{
The Risk-Adjusted Performance of Alternative Investment Funds and UCITS: A Comparative Analysis
}

\author{
Silvio John Camilleri ${ }^{1} \&$ Ritienne Farrugia ${ }^{1}$ \\ ${ }^{1}$ Banking and Finance Department, Faculty of Economics, Management \& Accountancy, University of Malta, \\ Msida, Malta \\ Correspondence: Silvio John Camilleri, Banking and Finance Department, FEMA, University of Malta, Msida, \\ Malta. E-mail: silvio.j.camilleri@um.edu.mt
}

Received: April 30, 2018

doi:10.5539/ijef.v10n7p23
Accepted: May 18, 2018

Online Published: May 30, 2018

URL: https://doi.org/10.5539/ijef.v10n7p23

\begin{abstract}
This study evaluates the performance of a selection of Alternative Investment Funds (AIFs), and Undertakings for Collective Investment in Transferable Securities Funds (UCITS) which followed a global geographic focus strategy during the period 2010-2016. These two fund structures are governed by different regulatory frameworks, which have evolved and re-shaped over the years. Various yardsticks are employed to evaluate the risk-adjusted performance of the sampled funds, and Monte-Carlo simulations are used to gauge the possible out-of-sample returns. Most of the sampled funds underperformed the benchmark index in terms of their Sharpe and Treynor ratios. Whilst UCITS registered a better overall performance, AIFs outperformed UCITS towards the end of the sample period. This suggests that investors should not assume that one fund structure is inherently superior to the other, since the relative performance may vary over time.
\end{abstract}

Keywords: AIFs, collective investment funds, performance evaluation, performance persistence, Sharpe ratio, Treynor ratio, UCITS, value-at-risk

\section{Introduction}

The European asset management industry has grown by 77\% between 2006 and 2016 and this market ranks as the second largest one in the world after the US since it accounts for $31 \%$ of global assets (EFAMA, 2017). The asset management industry comprises discretionary mandates from institutional clients, and investment fund structures where participants purchase and redeem units of a fund.

The size of the industry and the potential for further growth imply a crucial necessity for suitable regulation. Various regulatory frameworks have evolved to enhance the mobility of asset management business whilst emphasising investor protection, especially at the retail level. Undertakings for Collective Investments in Transferable Securities (UCITS) and Alternative Investment Funds (AIFs) are the main fund vehicles prevalent in the European Union (EU).

The regulatory frameworks which govern UCITS and AIFs establish several parameters to be followed by the investment managers. Despite that the regulations which govern these structures seem to have converged over the years, the remaining distinctions may still translate in differences in terms of the inherent risk and profitability.

The purpose of this paper is to evaluate the risk-adjusted performance of collective investment schemes (CISs) which are set up as per the above two structures. We therefore use a sample of thirty funds which follow a global geographic focus strategy and estimate risk-adjusted performance yardsticks using their monthly returns for the period 2010-2016.

We apply various metrics to measure the performance of the funds and to determine whether any of the two structures generated superior results on a consistent basis. Given that UCITS are often marketed at retail level which is not usually the case with AIFs - one may expect the former to adopt less risky strategies. It is an additional scope of this paper to assess whether this is indeed the case.

The rest of the paper is structured as follows. Section 2 offers a contextual background which highlights the main issues explored in prior research, summarises the differences between UCITS and AIFs, and describes the metrics used for assessing fund performance. Section 3 outlines the methodology while section 4 describes the 
data. We then employ different yardsticks in section 5 to evaluate the relative performance of the respective fund groups. Section 6 concludes.

\section{Contextual Background and Prior Literature}

\subsection{Salient Issues in Fund Management Performance}

Prior studies which compare the performance of different fund categories are numerous and a detailed review goes beyond the scope of this section. Authors have proposed different methodologies and ratios which may be used in performance comparisons, including the ones shown in sub-section 2.3.

One central aspect in fund management literature is the issue of whether active investment strategies outperform passive holdings in a general-market portfolio. In the context of US mutual funds, Malkiel (1995) reported that an indexing strategy performs better than active fund management, and similar conclusions were found by Zimmermann and Zogg-Wetter (1992) and Griese and Kempf (2003) in the context of Swiss and German equity funds respectively.

Research has also focused on whether funds which outperform the market during a particular period, retain superior performance at a subsequent stage. Kosowski et al. (2006) reported persistence of superior returns for US growth-oriented funds, but not for income-oriented funds. In the study of Bollen and Busse (2005), persistence proved sensitive to the yardstick which was used to evaluate performance.

Prior studies have also delved on whether familiarity with the market where the investment takes place may impact on the performance of a fund. Shukla and Van Inwegen (1995) and Coval and Moskowitz (2002) reported that local investors in a given market performed better than overseas ones, and this could be due to informational advantages. Contrasting evidence was found by Curkovic and Kristo (2017) who investigated the performance of UCITS active in Croatia and reported that funds administered by overseas-based managers generated higher absolute returns.

Literature has also explored the relationship between fund performance and the quantity of assets under management. Studies seem to support both the notions of economies of scale and diseconomies of scale. For instance, Indro et al. (1999) suggested that there is a minimum size threshold that a fund must exceed to generate an acceptable return, yet a higher threshold also exists where diseconomies of scale are experienced. Evidence of diseconomies of scale was also reported by Chen et al. (2004) who found that smaller funds perform better than larger ones and that the impacts of diseconomies of scale may be sensitive to the asset holdings of the funds. Despite this, the authors also reported that larger funds enjoy cost advantages. Curkovic and Kristo (2017) reported that Croatian UCITS with more assets under management registered better performance.

\subsection{Collective Investment Schemes: UCITS and AIFs}

CISs vary in terms of the strategy and risk tolerance adopted by their managers, and therefore a CIS which may be appropriate for professional investors may not be suited for retail ones. In case of the EU, fund structures such as UCITS and AIFs may be registered in line with relevant regulatory directives.

The UCITS Directive (2014) establishes a framework to enable UCITS to be marketed across the EU, once they are licensed in any of the respective member states. The Directive is also concerned with the safeguarding of UCITS holders by requiring that the fund provides a relatively stable investment outlet and therefore it imposes specific obligations such as the ones below.

UCITS may only invest in transferable securities, money market instruments, units of other UCITS or CISs, deposits with credit institutions, and financial derivatives. Specific criteria should be followed when investing in these assets. For instance, securities or money market instruments should be traded publicly. Additionally, UCITS are subject to thresholds in respect of percentages which may be invested with different issuers and in different types of instruments. In the evolution of UCITS regulation, noteworthy debates ensued regarding which kinds of derivatives should such funds be permitted to invest in (Lhabitant, 2007). Cumming et al. (2011) reported that the comprehensive investor protection offered in the context of UCITS resulted in extended popularity in terms of distribution networks.

Alternative Investment Funds (AIFs) constitute another investment structure and when these schemes are not marketed to retail investors, they may adopt more complex investment strategies. The operations of AIF managers are regulated at EU level by the Alternative Investment Fund Managers Directive (AIFMD). The Directive is aimed at regulating AIF managers based in the EU, as well as non-EU AIF managers whose products are marketed in the EU, or those that manage AIFs originating from the EU. As per the AIFMD, all collective investment undertakings that are not classified as UCITS fall under the AIFs category. Therefore, undertakings 
such as hedge funds, private equity funds, venture capital, and real estate funds are classified as AIFs under the EU regulatory framework (Nabilou, 2017).

Unlike UCITS, AIFs may employ leverage and managers should specify the degree of leverage to be permitted for the AIF (Note 1). AIFs are required to implement predetermined systems to monitor and manage liquidity risks. AIFs are usually marketed to professional investors only, although the Directive qualifies that EU member states may permit marketing of AIFs to retail investors provided that they carry out assessments to determine the appropriateness of doing so. Stricter requirements may be imposed when marketing at retail level takes place.

Overall, one may expect UCITS to adopt a relatively conservative approach, given that AIFs are permitted to pursue riskier strategies such as leverage. For instance, the UCITS Directive specifies the type of assets in which UCITS may invest, whereas such restrictions are not applicable to AIFs.

\subsection{Measuring Portfolio Performance}

Various scholars were intrigued by the construction and performance of portfolios, particularly Treynor (1965), Sharpe (1964), and Jensen (1967), who built on the findings of Markowitz (1959). These scholars made similar assumptions with respect to investors, in that the latter are rational and risk averse and formulate homogenous expectations (Jensen, 1967). Sharpe (1964) proposed that investors are "able to attain any desired point along a capital market line" in terms of a risk-return framework (pp. 425-426). The capital market line may be obtained through a combination of a risk-free asset and a diversified market portfolio where risk only constitutes of the systemic type (since company-specific risk may be avoided through diversification).

In their work, Sharpe (1964) and Treynor (1965) proposed methods through which mutual fund performance may be measured in terms of a risk-return trade off. The Treynor Ratio considers the excess return of an investment or portfolio, for each unit of market risk as shown in Equation 1.

$$
\text { Treynor Ratio }=\frac{R_{p}-R_{f}}{\beta_{p}}
$$

where $R_{p}$ is the return of the portfolio over the given period, $R_{f}$ is the return generated by the riskless asset over the given period, and $\beta_{p}$ represents the systematic risk of the portfolio and is estimated by the formula:

$$
\operatorname{Beta}=\beta_{p}=\frac{\operatorname{Cov}\left(R_{p}, R_{m}\right)}{\sigma_{m}^{2}}
$$

where $R_{m}$ is the return of the market portfolio and $\sigma_{m}^{2}$ is the variance of the market portfolio.

A similar metric to the Treynor Ratio was developed by Sharpe (1966) and is named the reward-to-variability ratio or the Sharpe Ratio. This metric measures the excess return per unit of risk, where the latter refers to total volatility - which could emanate from systematic and company-specific risk. In this way, the Sharpe ratio is also capturing the portion of volatility that is due to lack of diversification. The Sharpe Ratio is computed as shown in Equation 3.

$$
\text { Sharpe Ratio }=\frac{R_{p}-R_{f}}{\sigma_{p}}
$$

where $\sigma_{p}$ is the standard deviation of the portfolio over the given period. The Sharpe Ratio is a commonly used metric, and Eling and Schuhmacher (2007) empirically found that when it is used to rank the performance of a group of funds, it yields results which are similar to a variety of other yardsticks even if the underlying returns deviate from normality. Similarly, Casarin et al. (2005) and Hsu et al. (2012) reported a high correlation between Sharpe Ratios and Treynor Ratios.

Another yardstick used to gauge a portfolio's performance is the Jensen's Alpha (1967). This metric requires the estimation of a model of the portfolio's returns vis-à-vis the general market returns. The intercept of this regression is referred to as the alpha of the portfolio, and it represents the average additional return independent of market movements. The slope coefficient of the regression may also be interpreted as a proxy of the systematic risk due to its correlation with the market portfolio.

Whilst the above metrics are widely used on the grounds that they permit a comparison of the performance of a portfolio while taking risk into account, one should note that they may not necessarily be indicative of future performance. For instance, Glode (2011) discussed how it might still be sensible to buy a fund which has registered a negative alpha. Similarly, the Sharpe ratio may not always be indicative of the actual investment skills of a portfolio manager (Goetzmann et al., 2007). The authors also reported that the use of standard deviation as a measure of risk in the Sharpe ratio is not sufficiently rigorous to take account of tail risks. Indeed, 
volatility of stock prices [and therefore the Net Asset Values (NAVs) of funds] may be influenced by a variety of factors such as dividend payments (Shah \& Noreen, 2016; Camilleri et al., 2018) and market structure (Amihud \& Mendelson, 1987; Camilleri, 2015), and therefore this yardstick might not be appropriate to capture all such nuances.

In this way it is important that when comparing portfolio performance, one does not over-rely on any particular measurement but counter-checks whether the indications are confirmed by other benchmarks. This paper applies the former performance yardsticks together with others, to determine whether UCITS or AIFs offered a better risk-return combination throughout the sample period. In addition, through using techniques such as value-at-risk estimations and Monte-Carlo simulations we explore factors which are side-lined in the above yardsticks, such as tail risks.

\section{Methodology}

In this paper we used a series of comparison yardsticks to investigate which fund structure generated superior risk-adjusted returns over the sample period, taking account of the underlying volatility risk. We started by compiling a summary of the objectives and holdings of the respective funds, to obtain a background of their investment strategies. We then calculated the logarithmic returns and other distributional data for the sampled funds. After compiling risk-return scatter plots to visually represent the location of the respective funds across these dimensions, we estimated value-at-risk (VAR) yardsticks and took different percentiles to establish the maximum loss with a pre-defined level of confidence.

Following this, we estimated the Jensen's Alpha, the Sharpe Ratio and the Treynor Ratio for each fund and tested whether the differences across UCITS and AIFs were statistically significant. We also computed the Sharpe Ratio and Treynor Ratio for each year to check whether there were any changes in trends across the sample period. Finally, we used Monte-Carlo simulations to generate random returns which replicated the distributional characteristics of the returns data of the respective funds. In this way, we established which fund group could be expected to register higher profits in the subsequent year.

In our calculations we abstracted from the fees charged by the funds due to data limitations. According to Fama and French (2010) quite a lot of funds do not generate benchmark-adjusted returns which are sufficient to cover their costs. Hence, whilst some funds may be found to generate abnormal returns when abstracting from fees, the latter may outweigh any excess returns.

\section{Data}

Given that the main objective of this study is to identify which fund structure registered superior performance, we selected funds with similar characteristics to enable a cleaner comparison. Therefore, we started with a list of UCITS and AIFs which was obtained through Thomson Reuters Eikon, and filtered it to select the sample as per the criteria underneath.

We only considered those funds which were active throughout the entire sample period. Funds in the process of mergers or liquidation were excluded from the sample since these actions are likely to cause changes in prices which may be unrelated to performance.

Funds included in this study were required to follow a global geographic focus strategy, as opposed to confining their holdings to a particular region or industry. This makes it more likely that any differences in performance do not emanate from the selection of a sector or geographical area targeted by the funds. For instance, prior research suggests that emerging and frontier markets may behave differently than their established counterparts (Miles, 2005; Camilleri \& Galea, 2009). In addition, the selected funds were required to follow an investment strategy focused on equity, fixed income or a mixture of both. Only accumulator funds were included in the sample. Distributor funds were excluded and therefore no data relating to dividend distribution or re-investment rates were required. This sampling process yielded thirty different funds comprising fourteen AIFs and sixteen UCITS. Lists of the sampled AIFs and UCITS (together with other information pertinent to section 5 of this paper) are shown in Appendix 1. Most of the sampled funds are domiciled in European countries except for nine AIFs domiciled in the Cayman Islands which is a British overseas territory.

In Table 1, we summarise the objectives and asset holdings of the funds to compile background information about their strategies. The funds which incorporated elements of tracking or used derivatives for hedging purposes were all UCITS. Money-market instruments were only included in UCITS portfolios. Relatively more AIFs held convertible securities and invested in other funds. Leverage, shorting possibilities, and low correlation with general markets were mentioned only in the case of AIFs. These observations suggest that AIFs follow riskier or more elaborate strategies. Other factors are less clear cut. For instance, a higher proportion of AIFs 
held fixed interest securities. The latter may be used in the context of relatively conservative strategies but may also be held for speculative bets on yield curve changes. The AIFs which held fixed interest securities all mentioned the objective of generating stable monthly returns, and therefore this would be more in line with a conservative strategy. While all UCITS hold equities, particular AIFs do not hold such securities and invest their holdings in other funds instead. Such policy may be used to attain a higher level of diversification, but it may also expose investors to more risky strategies. A higher percentage of AIFs referred to the hedging of currency exposure.

Table 1. Objectives and holdings of the sampled funds

\begin{tabular}{lcc}
\hline Panel A: Fund Objectives & UCITS & AIFs \\
\hline Stable Monthly Returns & $6 \%$ & $50 \%$ \\
Capital Gains (Short / Medium / Long Term) & $69 \%$ & $14 \%$ \\
Tracking & $13 \%$ & $0 \%$ \\
Responsible Investing & $6 \%$ & $0 \%$ \\
Hedging Currency Exposure & $6 \%$ & $36 \%$ \\
Value Investment & $6 \%$ & $0 \%$ \\
Low Correlation to Equity / Fixed Income & $0 \%$ & $50 \%$ \\
Short-selling (through other funds) & $0 \%$ & $57 \%$ \\
Leverage & $0 \%$ & $7 \%$ \\
\hline Panel B: Fund Holdings & UCITS & AIFs \\
\hline Cash / Money Market Instruments & $6 \%$ & $0 \%$ \\
Equities / Indirect investment in equities & $100 \%$ & $71 \%$ \\
Fixed Interest Securities & $31 \%$ & $43 \%$ \\
Convertible Securities & $13 \%$ & $43 \%$ \\
Other Funds & $25 \%$ & $100 \%$ \\
Use of Derivatives for Hedging & $6 \%$ & $0 \%$ \\
\hline
\end{tabular}

Note. The table summarises the objectives and asset holdings of the sampled AIFs and UCITS, in terms of the proportion of funds for which the particular objective / holding category applies. This summary was compiled through the fund fact sheets as at April 2017 obtained from Thomson Reuters Eikon.

The final data set included the NAVs of the selected funds at monthly intervals for seven years, from January 2010 to December 2016 (84 observations). Data for the MSCI World TR USD Index spanning over the same period at the same frequency were used as a benchmark where necessary. We selected this index since it is among the most popular benchmarks used by fund managers; in fact, it was specified as the benchmark of choice by over half of the funds included in this study. We also used the 3-month LIBOR data as a proxy for the risk-free rate. The NAV data were converted to logarithmic returns, as per equation 4.

$$
r_{t}=\ln \left(N A V_{t} / N A V_{t-1}\right)
$$

where $N A V_{t}$ is the net asset value per unit at time $t$.

As one would expect in case of financial data, Jarque-Bera (1980) tests rejected the hypothesis of a normal distribution of log returns for most funds. Durbin Watson (1971) tests showed that the log returns do not feature significant autocorrelation. Dickey Fuller Tests (1979) and Kwiatkowski-Phillips-Schmidt-Shin Tests (1992) were used to check for the presence of a unit root in the data. In case of the former tests, the null hypothesis of a unit root was rejected, while in case of the latter tests the null hypothesis of stationarity could not be rejected, suggesting that the log returns are stationary.

\section{Risk-Return Comparisons}

In this section we assess the performance of the sampled funds, using the MSCI World TR USD Index as a benchmark where applicable. As shown in Figures 1 and 2 the fund returns underperformed the benchmark for considerable parts of the sample period. Estimating the correlations of fund returns with index returns, UCITS registered an average correlation of 0.6867 whereas that of AIFs was 0.7417. A t-test on the individual correlations of UCITS as compared to those of AIFs, confirmed that the difference across the groups is significant at the $90 \%$ level of confidence (Note 2). 
Annualised Return of Alternative Investment Funds
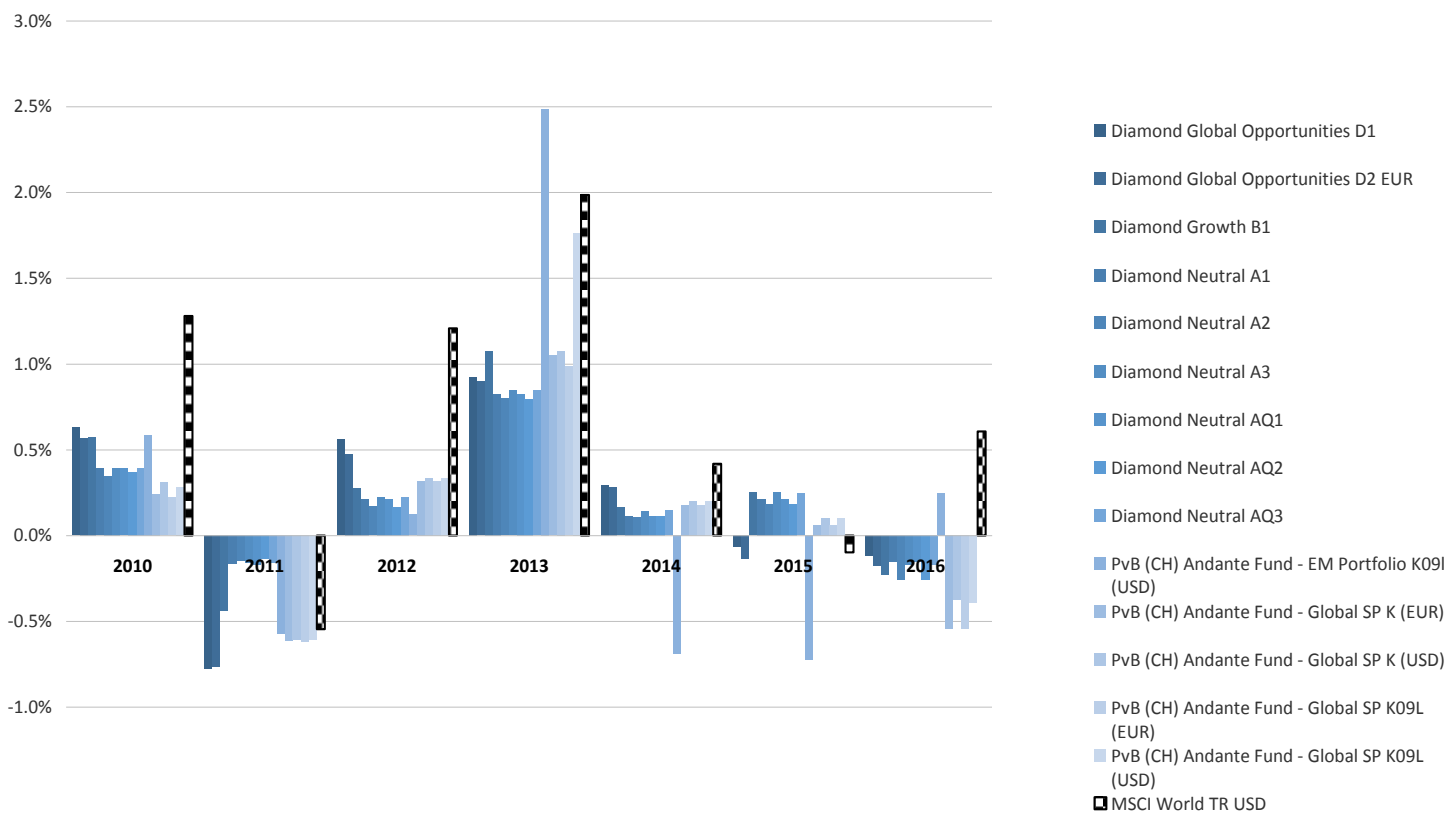

Figure 1. Comparing the annualised return of AIFs and MSCI world TR USD index

N.B. Solid colour bars represent AIF annualised returns, whereas the benchmark index returns are denoted by the checked bars towards the right for each respective year.

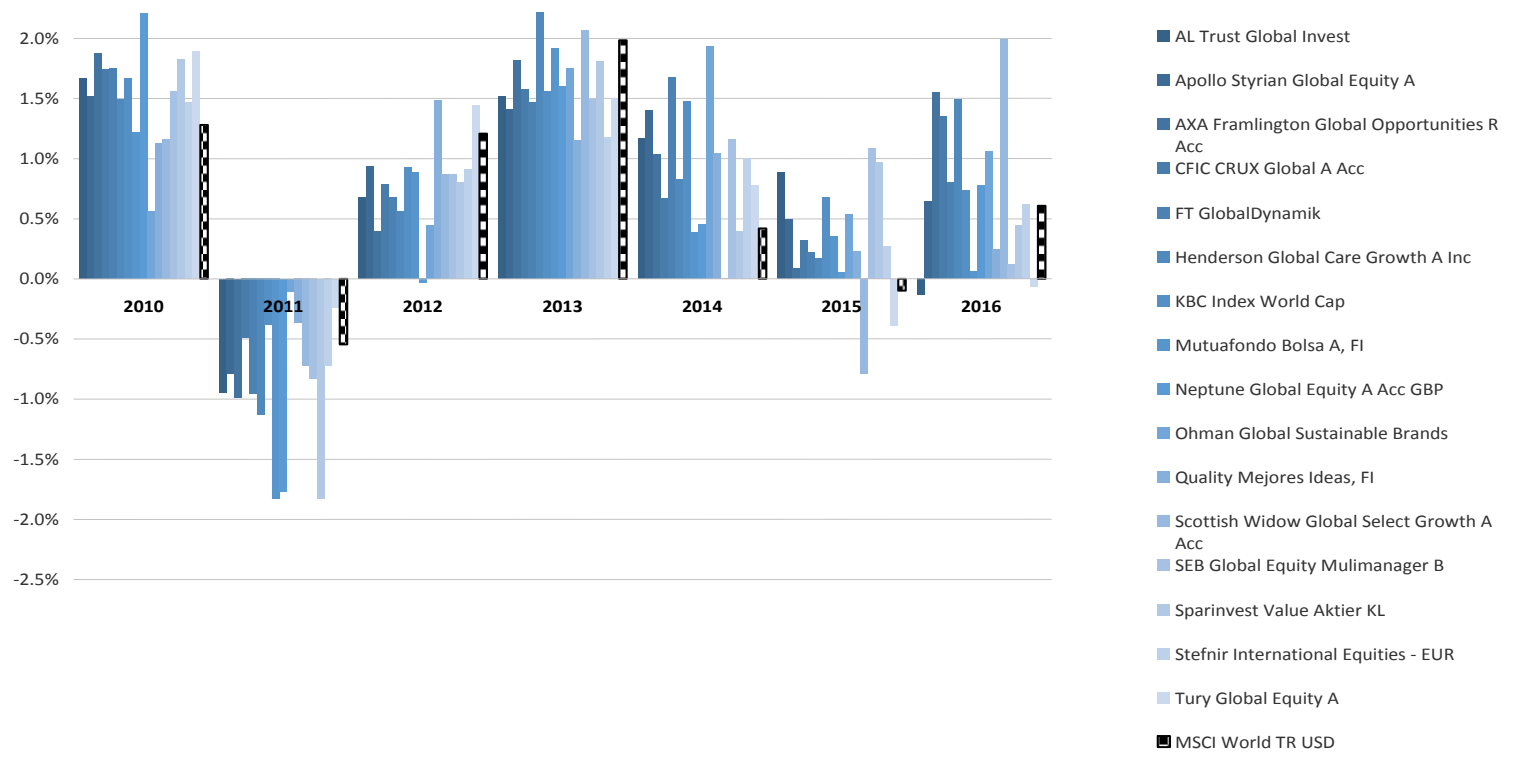

Figure 2. Comparing the annualised return of UCITS and MSCI world TR USD index

N.B. Solid colour bars represent UCITS annualised returns, whereas the benchmark index returns are denoted by the checked bars towards the right for each respective year.

The scatter plot in Figure 3 shows the risk-return combinations of the sampled funds. AIFs generated lower returns over the sample period, yet they proved less risky in terms of their return volatility. The overall higher UCITS returns were accompanied by higher return standard deviations (Note 3). This suggests that the sampled AIFs and UCITS adopted distinct investment strategies, although contrary to expectations it seems that the former followed more conservative policies which resulted in lower and more stable returns. 


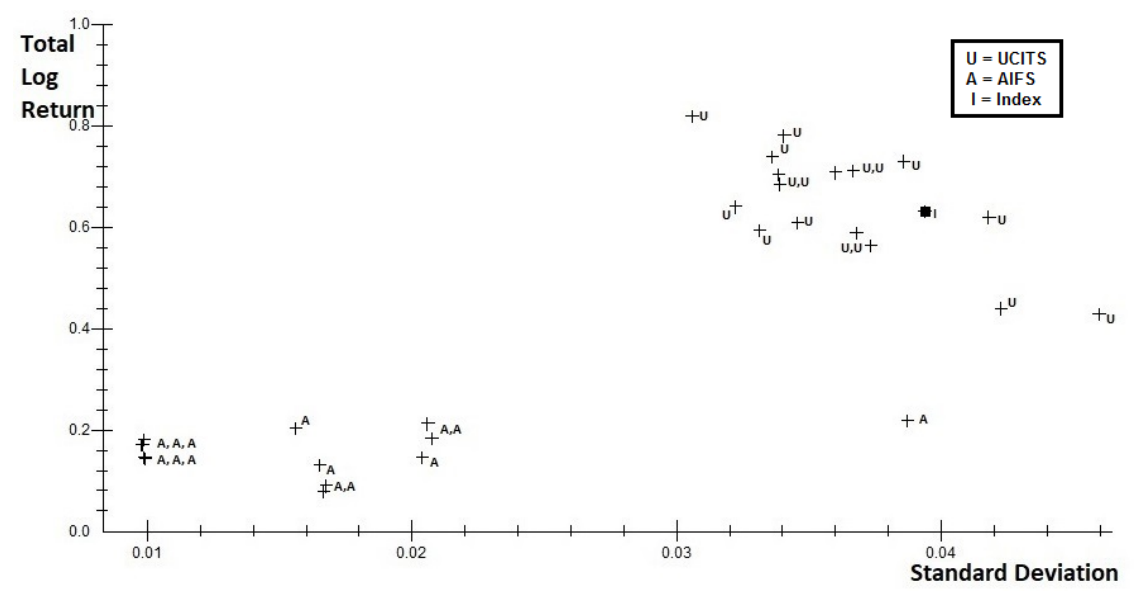

Figure 3. Scatter-plot of the risk-return Parameters of the sampled funds

NB: Each cross on the scatter diagram denotes the risk-return combination of a particular fund. The type of fund is identified by the letter A (for AIFs) or U (for UCITS). Letter I denotes the benchmark index.

A further insight regarding the inherent risk of the funds, can be garnered from VAR estimates. We took the historical VAR of the respective funds, by ordering the monthly log returns and taking the fifth and first percentiles. In case of the fifth percentile, we also calculated the conditional VAR, which in this case is the average of the lowest four observations. The average VAR estimates reported in Table 2 confirm that UCITS had a higher downside risk.

Table 2. Historical value-at-risk estimates

\begin{tabular}{lccc}
\hline & Average for AIFs & Average for UCITS & MSCI World TR USD Index \\
\hline 1-month VAR at 95\% Conf. Limit & -0.0218 & -0.0533 & -0.0674 \\
1-month CVAR at 95\% Conf. Limit & -0.0339 & -0.0791 & -0.0878 \\
1-month VAR at 99\% Conf. Limit & -0.0357 & -0.0868 & -0.0916 \\
\hline
\end{tabular}

Note. The table shows the averages of VAR and conditional VAR estimates of the respective fund groups. The historical VAR approach was used where the data for each fund were ordered and we considered two different percentiles of the left tail.

We then estimated market models to evaluate the association between the fund returns and the index. The summary statistics shown in Appendix 1 indicate that the slope coefficients were all significant at the 99\% level of confidence, but the intercepts of most models were insignificant. As per the Jensen's Alpha, the intercept of the market model "represents the average incremental rate of return on the portfolio" (Jensen, 1967, p. 397). Table 3 shows summary statistics for the alphas generated by the respective fund groups, where we note that UCITS generated higher alphas during the sample period. As reported in Appendix 1, the alphas for $88 \%$ of the UCITS were positive, whereas only $50 \%$ of AIFs registered positive alphas. T-tests conducted on the individual alphas of the respective funds showed that the difference between the alphas of AIF and UCITS is significant at the $99 \%$ level of confidence.

Table 3. Summary statistics for alphas generated by the funds

\begin{tabular}{lccc}
\hline & AIFs & UCITS & All Funds \\
\hline Mean & -0.00030 & 0.00294 & 0.00143 \\
Median & -0.00004 & 0.00349 & 0.00082 \\
Minimum & -0.00164 & -0.00228 & -0.00228 \\
Maximum & 0.00083 & 0.00639 & 0.00639 \\
\hline
\end{tabular}

Note. The table summarises the characteristics of the alphas generated by the respective fund groups. The alpha for each fund was estimated as the intercept from a market model. Details of the respective market models are shown in Appendix 1.

We next estimated the Sharpe Ratio, where the excess return of each fund is divided by the standard deviation of returns as a proxy for risk, as shown in Equation 3. For each fund, the ratio was computed for the entire period, 
as well as on yearly basis. The Sharpe Ratio of all the funds (and that of the index) was negative when considering the entire period, suggesting that one would have fared better when investing at the risk-free rate. As shown in Table 4 Panel A, UCITS registered a better performance than AIFs, and t-tests conducted on the Sharpe Ratios of the respective funds showed that the difference is significant at the $99 \%$ level of confidence. Further insights emerge when considering the Sharpe Ratios on an annual basis (Figure 4). UCITS recorded a better average than AIFs during most years, except for 2015 and 2016. Nonetheless, the overall performance of UCITS was still worse than that of the benchmark except for the years 2014 and 2015.

Table 4. Sharpe and treynor ratios of sampled funds

\begin{tabular}{|c|c|c|}
\hline \multicolumn{3}{|c|}{ Panel A: Summary of Sharpe Ratios } \\
\hline & AIFs & UCITS \\
\hline Mean & -2.093 & -0.629 \\
\hline Median & -1.787 & -0.636 \\
\hline Maximum & -0.720 & -0.545 \\
\hline Minimum & -2.906 & -0.715 \\
\hline Index & \multicolumn{2}{|c|}{-0.582} \\
\hline \multicolumn{3}{|c|}{ Panel B: Summary of Treynor Ratios } \\
\hline & AIFs & UCITS \\
\hline Mean & -0.112 & -0.037 \\
\hline Median & -0.090 & -0.036 \\
\hline Maximum & -0.057 & -0.026 \\
\hline Minimum & -0.160 & -0.053 \\
\hline Index & \multicolumn{2}{|c|}{-0.023} \\
\hline
\end{tabular}

Note. The table shows the summary statistics of the Sharpe Ratios of AIFs and UCITS for the period 2010-2016. The ratios of the benchmark index are shown underneath.

The Treynor Ratio shown in Equation 1 estimates the excess return of a portfolio for each unit of market risk, where the latter is measured in terms of beta. As shown in Table 4 Panel B, the funds generated negative Treynor ratios during the sample period, and t-tests conducted on the Treynor Ratios showed that the difference between fund groups is significant at the $99 \%$ level of confidence. Considering the Treynor Ratio on an annual basis, the performance of AIFs is worse than that of UCITS up to and including 2014. Subsequently, both fund structures generated a positive return per unit of risk, with AIFs registering better performance than UCITS (Figure 5).

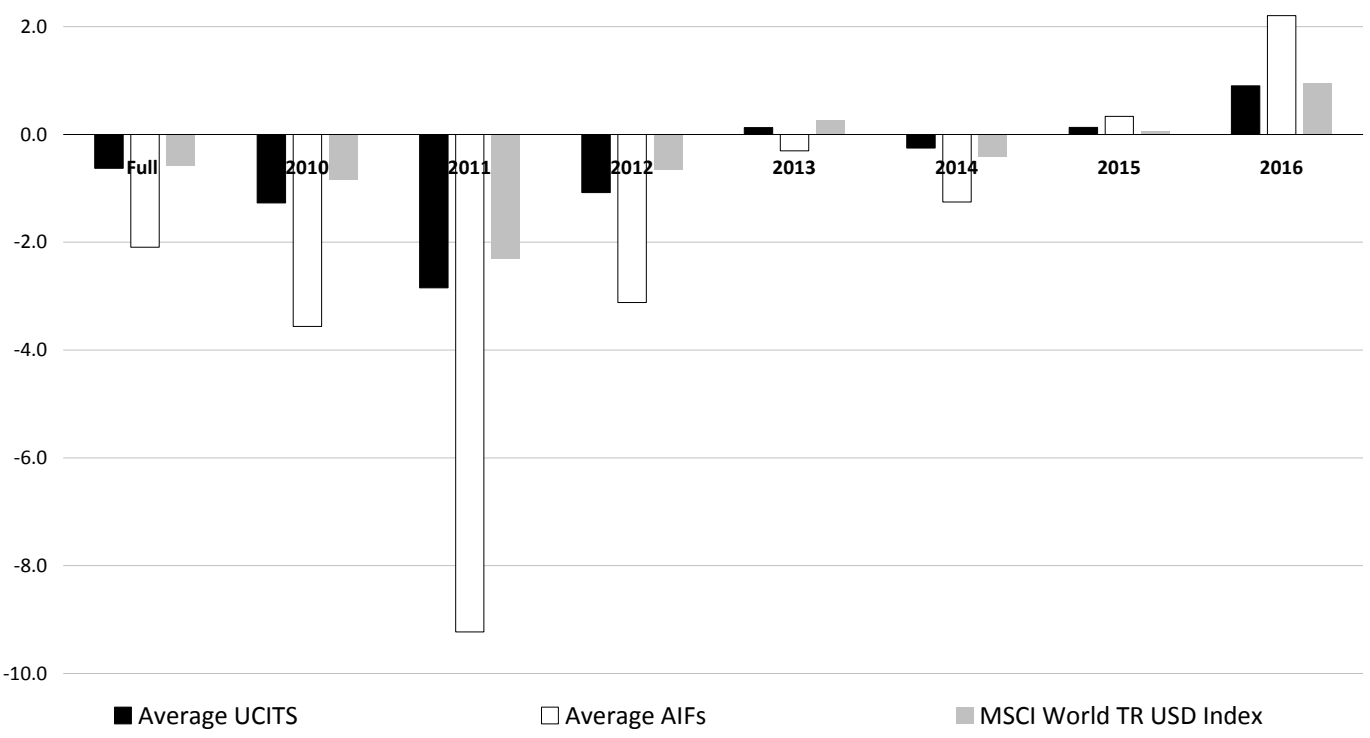

Figure 4. Average sharpe ratios for AIFs, UCITS and the index on an annual basis 


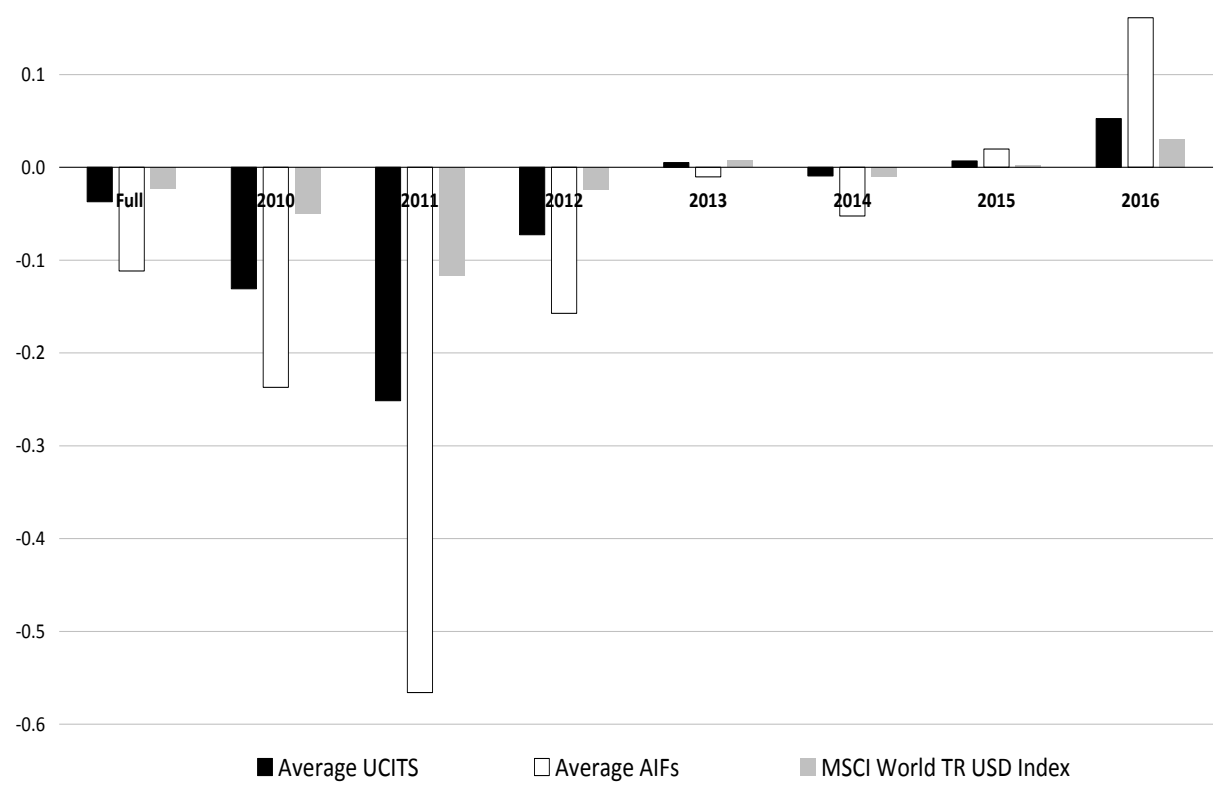

Figure 5. Average treynor ratios for AIFs, UCITS and the index on an annual basis

The fact that AIFs outperformed UCITS during 2015 and 2016 in contrast with the prior sub-period merits further discussion. This change could have been either due to the respective strategies of the funds proving more / less profitable at different points in time, or due to the funds changing their investment strategy in the final part of the sample period, or due to a combination of both possibilities. When re-estimating the correlations of fund returns with the benchmark for these two sub-periods, we noted that the returns of AIFs were significantly less correlated with the world index in the final two years (Table 6). This may indicate a change where the underlying strategies became less dependent on general market movements.

Table 5. Monte-carlo simulations of expected profits in the subsequent year

\begin{tabular}{lcccccc}
\hline UCITS & Average & Median & St.Devn. & \multicolumn{3}{c}{ Percentiles } \\
\cline { 5 - 7 } & & & & $1 \%$ & $5 \%$ & $25 \%$ \\
\hline AL Trust Global Invest & 1.0900 & 1.0934 & 0.1255 & 0.8194 & 0.8806 & 1.0036 \\
Apollo Styrian Global Equity A & 1.1030 & 1.0900 & 0.1356 & 0.8363 & 0.9025 & 1.0122 \\
AXA Framlington Global Opportunities & 1.1127 & 1.1048 & 0.1476 & 0.7977 & 0.8911 & 1.0122 \\
CFIC CRUX Global A Acc & 1.1074 & 1.0998 & 0.1278 & 0.8402 & 0.9122 & 1.0147 \\
FT Global Dynamik & 1.1039 & 1.0980 & 0.1302 & 0.8136 & 0.9050 & 1.0133 \\
Henderson Global Care Growth A Inc & 1.1132 & 1.1050 & 0.1354 & 0.8144 & 0.8998 & 1.0234 \\
KBC Index World Cap & 1.1331 & 1.1292 & 0.1207 & 0.8936 & 0.9454 & 1.0463 \\
Mutuafondo Bolsa A, FI & 1.0653 & 1.0503 & 0.1703 & 0.7245 & 0.7992 & 0.9454 \\
Neptune Global Equity A Acc GBP & 1.0606 & 1.0528 & 0.1512 & 0.7596 & 0.8281 & 0.9461 \\
Ohman Global Sustainable Brands & 1.1170 & 1.1067 & 0.1324 & 0.8446 & 0.9219 & 1.0237 \\
Scottish Widows Global Select Growth & 1.0872 & 1.0780 & 0.1347 & 0.8206 & 0.8812 & 0.9907 \\
SEB Global Equity Multimanager B & 1.1042 & 1.0954 & 0.1336 & 0.8248 & 0.8937 & 1.0134 \\
Sparinvest Value Aktier KL & 1.0768 & 1.0706 & 0.1398 & 0.7926 & 0.8607 & 0.9764 \\
Stefnir - International Equities - EUR & 1.0867 & 1.0793 & 0.1227 & 0.8345 & 0.8990 & 0.9998 \\
Tury Global Equity A & 1.0975 & 1.0881 & 0.1567 & 0.7731 & 0.8502 & 0.9806 \\
Quality Mejores Ideas, FI & 1.0946 & 1.0911 & 0.1196 & 0.8337 & 0.9100 & 1.0136 \\
Average across UCITS & $\mathbf{1 . 0 9 7 1}$ & $\mathbf{1 . 0 8 9 5}$ & $\mathbf{0 . 1 3 6 5}$ & $\mathbf{0 . 8 1 4 0}$ & $\mathbf{0 . 8 8 6 3}$ & $\mathbf{1 . 0 0 1 0}$ \\
\hline
\end{tabular}




\begin{tabular}{lcccccc}
\hline AIFs & Average & Median & St.Devn. & \multicolumn{3}{c}{ Percentiles } \\
\cline { 5 - 7 } & & & & $1 \%$ & $5 \%$ & $25 \%$ \\
\hline Diamond Neutral A2 & 1.0223 & 1.0217 & 0.0356 & 0.9410 & 0.9664 & 0.9973 \\
Diamond Neutral A1 & 1.0253 & 1.0255 & 0.0329 & 0.9538 & 0.9707 & 1.0024 \\
Diamond Growth B1 & 1.0306 & 1.0292 & 0.0562 & 0.9061 & 0.9373 & 0.9935 \\
PvB Andante - Global SP K (EUR) & 1.0146 & 1.0131 & 0.0600 & 0.8804 & 0.9197 & 0.9737 \\
PvB Andante - Global SP K (USD) & 1.0242 & 1.0232 & 0.0608 & 0.8932 & 0.9283 & 0.9813 \\
Diamond Neutral A3 & 1.0263 & 1.0257 & 0.0348 & 0.9485 & 0.9697 & 1.0013 \\
Diamond Global Opportunities D2 EUR & 1.0249 & 1.0228 & 0.0717 & 0.8672 & 0.9101 & 0.9767 \\
Diamond Global Opportunities D1 & 1.0290 & 1.0284 & 0.0730 & 0.8532 & 0.9102 & 0.9819 \\
Diamond Neutral AQ2 & 1.0205 & 1.0218 & 0.0355 & 0.9387 & 0.9636 & 0.9965 \\
Diamond Neutral AQ1 & 1.0258 & 1.0252 & 0.0349 & 0.9502 & 0.9687 & 1.0023 \\
Diamond Neutral AQ3 & 1.0256 & 1.0247 & 0.0353 & 0.9433 & 0.9666 & 1.0032 \\
PvB Andante - EM Portf. K09L (USD) & 1.0295 & 1.0205 & 0.1405 & 0.7473 & 0.8175 & 0.9314 \\
PvB Andante - Global SP K09L (USD) & 1.0331 & 1.0321 & 0.0736 & 0.8762 & 0.9173 & 0.9803 \\
PvB Andante - Global SP K09L (EUR) & 1.0157 & 1.0130 & 0.0604 & 0.8849 & 0.9215 & 0.9742 \\
Average across AIFs & $\mathbf{1 . 0 2 4 8}$ & $\mathbf{1 . 0 2 3 4}$ & $\mathbf{0 . 0 5 7 5}$ & $\mathbf{0 . 8 9 8 8}$ & $\mathbf{0 . 9 3 3 4}$ & $\mathbf{0 . 9 8 5 4}$ \\
MSCI World TR USD Index & $\mathbf{1 . 0 9 7 9}$ & $\mathbf{1 . 0 8 5 2}$ & $\mathbf{0 . 1 4 7 4}$ & $\mathbf{0 . 7 9 9 2}$ & $\mathbf{0 . 8 8 1 7}$ & $\mathbf{0 . 9 9 1 5}$ \\
\hline
\end{tabular}

Note. In these Monte-Carlo simulations we generated twelve random monthly returns for each fund, based on the underlying moments of the respective historical distributions. The returns were compounded to estimate the hypothetical return after one year for every fund, and the procedure was repeated 1,000 times. The table summarises the projected returns for each fund in terms of the averages, medians, standard deviations and percentiles of the 1000 iterations.

We assumed an initial investment of one dollar. Therefore, the first figure shown on the table means that the particular fund generated a return of $9 \%$ over the one-year horizon, when considering the average results of the 1,000 Monte-Carlo iterations.

Table 6. Correlations with the MSCI World TR USD index for the sub-periods

\begin{tabular}{lcc}
\hline & $\mathbf{2 0 1 0} \mathbf{- 2 0 1 4}$ & $\mathbf{2 0 1 5 - 2 0 1 6}$ \\
\hline Average for UCITS & 0.6815 & 0.7291 \\
Average for AIFs & 0.7705 & 0.6389 \\
\hline
\end{tabular}

Note. Paired t-tests on correlations for individual UCITS and AIFs were conducted to check whether the differences over the respective periods were statistically significant. Whilst the increase in correlation for UCITS was insignificant, the reduction in correlation for AIFs was significant at the $95 \%$ level of confidence.

Finally, we used Monte-Carlo simulations to investigate the expected profitability differences between AIFs and UCITS for the subsequent year. For each fund, we generated twelve random monthly returns based on the underlying moments of the respective historical distributions and compounded these to estimate the hypothetical return after one year. This procedure was repeated 1,000 times for each fund, noting down the projected random return after one year following each iteration. The average projected return for each fund is reported in Table 5, together with the median, standard deviation and percentiles. We note that based on past performance, UCITS could be expected to remain more profitable on average in the subsequent year. Despite this, considering the first and fifth percentiles of the projected returns, it transpires that when focusing on the worst performing iterations, AIFs may be expected to perform better, suggesting lower tail risks.

\section{Conclusion}

In this study we used a battery of yardsticks to assess the relative performance of a sample of UCITS and AIFs. Overall, UCITS generated significantly higher returns during the sample period, and Monte-Carlo simulations indicated that one could reasonably expect such trend to persist in the subsequent year.

Risk-return plots suggest that higher UCITS returns were accompanied by higher return volatility while VAR estimates indicate that UCITS had a higher downside risk. These findings may possibly be attributed to a tendency on part of UCITS managers to adopt riskier strategies due to unclear regulatory factors relating to the then-proposed AIFMD (Varriale, 2011; Grima et al., 2016). AIFs featured higher correlation with the MSCI World TR USD Index, although this characteristic was not consistent throughout the sample period. Despite the indications that UCITS proved riskier in terms of their return volatility, the latter still offered a more efficient risk-return trade-off than AIFs in terms of higher Sharpe ratios and Treynor ratios. UCITS also generated higher alphas.

Whilst UCITS registered a better overall performance, when considering the results on an annual basis we noted 
that AIFs outperformed UCITS towards the end of the sample period. This may be due to the possibility that the strategies adopted by AIFs changed somewhat during the final two years, as suggested by changes in their return correlation with the benchmark index.

The above findings caution investors not to assume that UCITS should prove less volatile than AIFs or more correlated with the general market due to more onerous regulatory restrictions. This seems in line with the findings of Darolles (2014) who reported that regulations may differ in their impacts on UCITS, depending on the strategies of the latter. Prior literature also documents a trend for some UCITS categories to take on strategies that were formerly associated with offshore hedge funds following the 2007 financial crisis (Busack et al., 2014). This may suggest a tendency on part of UCITS to take on higher risks, which coupled with the recent increased investor protection offered through AIFMD may also lead to convergence in the regulatory frameworks of UCITS and AIFs, as discussed by Moloney (2014, p. 284).

In addition, we found that the relative performance of these fund structures may vary over time. This is consistent with prior studies which found no evidence of performance persistence across funds (Bialkowski \& Otten, 2011; Prather et al., 2004), but in contrast with other literature which supports performance persistence (Abudy et al., 2016; Ammann et al., 2010; Brown \& Goetzmann, 1995; Dawe et al., 2014).

One should also note that most funds (from both categories) underperformed the benchmark index in terms of the overall Sharpe and Treynor ratios. This implies that a passive tracking strategy (or even investing at the risk-free rate) would have been more profitable in the circumstances. Overall, this confirms prior studies which suggest that only a small number of portfolios generate positive returns which are sufficient to cover the fees relating to their management (Fama \& French, 2010) and that finance professionals' opinions may not necessarily outperform randomly-formed portfolios over the longer term (Shaikh et al., 2011).

These insights ought to be interpreted in the context of the limitations of the study. Given the different parameters under which UCITS and AIFs operate, their strategies may differ substantially and thus the chosen benchmark might not be appropriate for both (Zhu, 2014). Having said this, it is advantageous to assess the performance of the respective funds using a single benchmark for the sake of an unambiguous comparison. We did not account for different fund sizes within the sample that might give rise to economies or diseconomies of scale and impact on other fund characteristics (Berk \& Green, 2004; Brown \& Wu, 2016; Pástor et al., 2015). In addition, we abstracted from transaction costs and due to the criteria specified in the sampling process, the selected funds may not be representative of the entire population.

The Monte-Carlo simulations do not account for changes in the underlying market conditions; for instance, changes in liquidity may impact significantly on returns (Anthonisz \& Putnins, 2016). The way in which funds were sampled is prone to survivorship bias since we only considered those funds which were active throughout the entire sample period. This may tilt results in favour of better performing entities, because underperforming funds are more likely to exit the market (Lai \& Wang, 2016) and the merging of funds may be connected with unsatisfactory perfromance (Wang \& Huang, 2013). Finally, given that the NAVs of the funds depend on the prices of the underlying holdings such as stocks, the former are prone to unaccounted-for factors such as stock price seasonality (Camilleri, 2008; Lucey\& Whelan, 2004), and non-synchronous trading effects (Day \& Wang, 2002; Camilleri \& Green, 2014).

As for future research possibilities, the profitability of investment funds may be assessed whilst accounting more fully for the differences in asset holdings since these are likely to impact on profitability trends. Given that the traditional two-dimensional risk-return framework may prove too simplistic to gauge the intricacies of portfolio performance, the latter may also be explored through other methodologies which were proposed more recently such as data envelopment analysis (Gregoriou et al., 2005) and peer performance ratios (Ardia \& Boudt, 2018). The fund management industry is continuously evolving, and more elaborate products are offered on a consistent basis. Funds may be set up to profit from market mispricings or to track particular aspects of an index (such as capital gains or dividend yields). These initiatives are likely to offer further potential for additional research regarding the relative performance of different types of CISs.

\section{References}

Abudy, M., Barel, M., \& Wohl, A. (2016). Performance of Israeli mutual funds: Equity and bond funds. Israel Economic Review, $13, \quad 1-21 . \quad$ Retrieved $\quad$ from http://www.boi.org.il/en/Research/Periodicals/Documents/13.01.pdf

Amihud, Y., \& Mendelson, H. (1987). Trading mechanisms and stock returns: An empirical investigation. Journal of Finance, 42, 533-553. https://doi.org/10.1111/j.1540-6261.1987.tb04567.x 
Ammann, M., Huber, O., \& Schmid, M. (2010). Hedge fund characteristics and performance persistence. European Financial Management, 19, 209-250. https://doi.org/10.1111/j.1468-036X.2010.00574.x

Anthonisz, S. A., \& Putnins, T. J. (2016). Asset pricing with downside liquidity risks. Management Science, 63, 2549-2572. https://doi.org/10.1287/mnsc.2016.2438

Ardia, D., \& Boudt, K. (2018). The peer performance ratios of hedge funds. Journal of Banking and Finance, 87, 351-368. https://doi.org/10.1016/j.jbankfin.2017.10.014

Berk, J., \& Green, R. (2004). Mutual fund flows and performance in rational markets. Journal of Political Economy, 112, 1269-1295. https://doi.org/10.1086/424739

Bialkowski, J., \& Otten, R. (2011). Emerging market mutual fund performance: Evidence for Poland. North American Journal of Economics and Finance, 22, 118-130. https://doi.org/10.1016/j.najef.2010.11.001

Bollen, N., \& Busse, J. (2005). Short-term persistence in mutual fund performance. Review of Financial Studies, 18, 569-597. https://doi.org/10.1093/rfs/hhi007

Brown, D. P., \& Wu, Y. (2016). Mutual fund flows and cross-fund learning within families. Journal of Finance, 71, 383-424. https://doi.org/10.1111/jofi.12263

Brown, S. J., \& Goetzmann, W. N. (1995). Performance persistence. Journal of Finance, 50, 679-698. https://doi.org/10.1111/j.1540-6261.1995.tb04800.x

Busack, M., Drobetz, W., \& Tille, J. (2014). Do alternative UCITS deliver what they promise? A comparison of alternative UCITS and hedge funds. Applied Financial Economics, 24, 949-965. https://doi.org/10.1080/09603107.2014.916386

Camilleri, S. J. (2008). Month-related seasonality of stock price volatility: Evidence from the Malta Stock Exchange. Bank of Valletta Review, 37, 49-65. Retrieved from https://www.bov.com/documents/bov-review-37-paper-4

Camilleri, S. J. (2015). Do call auctions curtail price volatility? Evidence from the National Stock Exchange of India. Managerial Finance, 41, 67-79. https://doi.org/10.1108/MF-10-2013-0292

Camilleri, S. J., \& Galea, G. (2009). The diversification potential offered by emerging markets in recent years. The FEMA Research Bulletin, 1, 21-37.

Camilleri, S. J., \& Green, C. J. (2014). Stock market predictability: Non-synchronous trading or inefficient markets? Evidence from the national stock exchange of India. Studies in Economics and Finance, 31, 354-370. https://doi.org/10.1108/SEF-06-2012-0070

Camilleri, S. J., Grima, L., \& Grima, S. (2018). The effect of dividend policy on share price volatility: An analysis of Mediterranean banks' stocks. Managerial Finance, forthcoming.

Casarin, R., Lazzarin, M., Pelizzon, L., \& Sartore, D. (2005). Relative benchmark rating and persistence analysis: Evidence from Italian equity funds. The European Journal of Finance, 11, 297-308. http://dx.doi.org/10.1080/1351847042000286658.

Chen, J., Hong, H., Huang, M., \& Kubik, J. (2004). Does fund size erode performance? The role of liquidity and organisation. American Economic Review, 94, 1276-1302. https://doi.org/10.1257/0002828043052277

Coval, J., \& Moskowitz, T. (2002). Home bias at home: Local equity preference in domestic portfolios. Journal of Finance, 54, 2045-2073. https://doi.org/10.1111/0022-1082.00181

Cumming, D., Imad'Eddine, G., \& Schwienbacher, A. (2011). Harmonized regulatory standards, international distribution of investment funds and the recent financial crisis. The European Journal of Finance, 18, 261-292. https://doi.org/10.1080/1351847X.2011.579743

Curkovic, M., \& Kristo, J. (2017). Performance measurement of UCITS investment funds in Croatia. UTMS Journal of Economics, $8, \quad 11-18 . \quad$ Retrieved from http://www.utmsjoe.mk/files/Vol.\%208\%20No.\%201/UTMSJOE-2017-0801-02-Curkovic-Kristo.pdf

Darolles, S. (2014). Evaluating UCITS Compliant Hedge Fund Performance. Working Paper, DRM-Université Paris Dauphine and CREST, Paris. https://dx.doi.org/10.2139/ssrn.1945798

Dawe, M. S., Pokhariyal, G. P., \& Mwaura, M. F. (2014). The performance persistence of equity and blended mutual funds in Kenya. International Journal of Economics and Finance, 6, 153-160. https://doi.org/10.5539/ijef.v6n8p153 
Day, T. E., \& Wang, P. (2002). Dividends, nonsynchronous prices, and the returns from trading the Dow Jones industrial average. Journal of Empirical Finance, 9, 431-454. https://doi.org/10.1016/S0927-5398(02)00004-X

Dickey, D. A., \& Fuller, W. A. (1979). Distribution of the estimators for autoregressive time series with a unit root. Journal of the American Statistical Association, 74, 427-431. https://doi.org/10.1080/01621459.1979.10482531

Durbin J., \& Watson, G. S. (1971). Testing for serial correlation in least-squares regression. Biometrika, 58, 1-19. https://doi.org/10.2307/2334313

EFAMA (European Fund and Asset Management Association). (2017). Asset Management in Europe: Facts and Figures. (9th ed.). Retrieved from http://www.efama.org/Publications/Statistics/Asset\%20Management\%20Report/EFAMA\%20Asset\%20Ma nagement\%20Report\%202017.pdf

Eling, M., \& Schuhmacher, F. (2007). Does the choice of performance measure influence the evaluation of hedge funds?. Journal of Banking and Finance, 31, 2632-2647. https://doi.org/10.1016/j.jbankfin.2006.09.015

Fama, E. F., \& French, K. R. (2010). Luck versus skill in the cross-section of mutual. The Journal of Finance, 65, 1915-1947. https://doi.org/10.1016/0304-4076(92)90104-Y

Glode, V. (2011). Why mutual funds "underperform". Journal of Financial Economics, 99, 546-559. https://doi.org/10.1016/j.jfineco.2010.10.008

Goetzmann, W., Ingersoll, J., Spiegel, M., \& Welch, I. (2007). Portfolio performance manipulation and manipulation-proof measures. Review of Financial Studies, 20, 1503-1546. https://doi.org/10.1093/rfs/hhm025

Gregoriou, G. N., Sedzro, K., \& Zhu, J. (2005). Hedge fund performance appraisal using data envelopment analysis. European Journal of Operational Research, 164, 555-571. https://doi.org/10.1016/j.ejor.2003.12.019

Griese, K., \& Kempf, A. (2003). Lohnt aktives fondsmanagement aus anlegersicht? Zeitschrift für Betriebswirtschaft, 73, 201-224.

Grima, S., Romānova, I., Bezzina, F., \& Chetcuti Dimech, F. (2016). Alternative investment fund managers directive and its impact on Malta's financial service industry. International Journal in Economics and $\begin{array}{llll}\text { Business } \quad \text { Administration, } & \text { 70-85. }\end{array}$ http://www.ijeba.com/index.php/journal/issues/32-volume-iv-2016/issue-1/120-alternative-investment-fund -managers-directive-and-its-impact-on-malta-s-financial-service-industry

Hsu, L. C., Ou, S. L., Yang, C. C., \& Ou, Y. C. (2012). How to choose mutual funds that perform well? Evidence from Taiwan. International Journal of Economics and Finance, 4, 247-259. https://doi.org/10.5539/ijef.v4n1p247

Indro D., Jiang C., Hu, M., \& Lee, W. (1999). Mutual fund performance: Does fund size matter?. Financial Analysts Journal, 55, 74-87. https://doi.org/10.2469/faj.v55.n3.2274

Jarque, C. M., \& Bera, A. K. (1980). Efficient tests for normality, homoscedasticity and serial independence of regression residuals. Economics Letters, 6, 255-259. https://doi.org/10.1016/0165-1765(80)90024-5

Jensen, M. C. (1967). The performance of mutual funds in the period 1945-1964. Journal of Finance, 23, 389-416. https://doi.org/10.1111/j.1540-6261.1968.tb00815.x

Kosowski, R., Timmermann, A., Wermers, R., \& White, H. (2006). Can mutual fund "stars" really pick stocks? New evidence from a bootstrap analysis. Journal of Finance, 61, 2551-2596. https://doi.org/10.1111/j.1540-6261.2006.01015.x

Kwiatkowski, D., Phillips, P. C., Schmidt, P., \& Shin, Y. (1992). Testing the null hypothesis of stationarity: How sure are we that economic time series. Journal of Econometrics, 54, 159-178. https://doi.org/10.1016/0304-4076(92)90104-Y

Lai, H. C., \& Wang, K. M. (2016). Does survivorship bias of mutual funds differ between liquidations and mergers? Eastern European Business and Economics Journal, 2, 299-314. Retrieved from http://eebej.eu/2016v2n4/299-314.pdf

Lhabitant, F. S. (2007). Hedge fund indices for retail investors: UCITS eligible or not eligible? Derivatives Use, 
Trading \& Regulation, 12, 275-289. $\quad$ Retrieved from https://link.springer.com/content/pdf/10.1057\%2Fpalgrave.dutr.1850054.pdf

Lucey, B. M., \& Whelan, S. (2004). Monthly and semi-annual seasonality in the Irish equity market 1934-2000. Applied Financial Economics, 14, 203-208. https://doi.org/10.1080/096031042000187397

Malkiel, B. G. (1995). Returns from investing in equity mutual funds 1971 to 1991. The Journal of Finance, 50, 549-572. https://doi.org/10.1111/j.1540-6261.1995.tb04795.x

Markowitz, H. M. (1959). Portfolio Selection, Efficient Diversification of Investments (16th ed.). John Wiley \& Sons, New York.

Miles, W. (2005). Do frontier equity markets exhibit common trends and still provide diversification opportunities? International Economic Journal, 19, 473-482. https://doi.org/10.1080/10168730500199475

Moloney, N. (2014). EU Securities and Financial Markets Regulation. Oxford University Press.

Nabilou, H. (2017). The conundrum of hedge fund definition. European Company and Financial Law Review, 14, 149-186. https://doi.org/10.1515/ecfr-2017-0006

Pástor, L', Stambaugh, R. F., \& Taylor, L. A. (2015). Scale and skill in active management. Journal of Financial Economics, 116, 23-45. https://doi.org/10.1016/j.jfineco.2014.11.008

Prather, L., Bertin, W., \& Henker, T. (2004). Mutual fund characteristics, managerial attributes, and fund performance. Review of Financial Economics, 13, 305-326. https://doi.org/10.1016/j.rfe.2003.11.002

Shah, S., \& Noreen, U. (2016). Stock price volatility and role of dividend policy: Empirical evidence from Pakistan. International Journal of Economics and Financial Issues, 6, 461-472. Retrieved from http://www.econjournals.com/index.php/ijefi/article/view/1752

Shaikh, F. M., Latif, A., Shah, A. A., \& Nazar, M. S. (2011). Forecasting the stock market through dart board theory. International Journal of Economics and Finance, 3, 106-112. https://doi.org/10.5539/ijef.v3n4p106

Sharpe, W. F. (1964). Capital asset prices: A theory of market equilibrium under conditions of risk. The Journal of Finance, 19, 425-442. https://doi.org/10.1111/j.1540-6261.1964.tb02865.x

Sharpe, W. F. (1966). Mutual fund performance. The Journal of Business, 39, 119-138. https://doi.org/10.1086/294846

Shukla, R., \& Van Inwegen, G. (1995). Do locals perform better than foreigners? An analysis of UK and US mutual fund managers. Journal of Economics and Business, 47, 241-54. https://doi.org/10.1016/0148-6195(95)00009-G

Treynor, J. L. (1965). How to rate management of investment funds. Harvard Business Review, 43, 63-75.

Varriale, G. (2011). UCITS gaining from AIFMD Uncertainty. International Financial Law Review, Jun 1, 2011. http://www.iflr.com/Article/2836823/Ucits-gaining-from-AIFMD-uncertainty. html

Wang, N.Y., \& Huang, C. J. (2013). What operational characteristics of mutual funds affect exit decisions and when? Evidence from Taiwan. International Journal of Economics and Finance, 5, 104-119. https://doi.org/10.5539/ijef.v5n5p104

Zhu, J. (2014). Quantitative models for performance evaluation and benchmarking: Data envelopment analysis with spreadsheets (3rd ed.). Springer: Massachusetts. https://doi.org/10.1007/978-3-319-06647-9

Zimmermann, H., \& Zogg-Wetter, C. (1992). Performance-messung schweizerischer aktienfonds: Markt-timing und selektivität. Swiss Journal of Economics and Statistics, 128, 133-159. Retrieved from http://www.sjes.ch/papers/1992-II-3.pdf

\section{Notes}

Note 1. UCITS may still engage in synthetic leverage when they take on exposures to derivatives.

Note 2. Overall, AIFs feature a higher correlation with the benchmark and lower betas (as compared to UCITS). This is explained by the fact that AIFs have a lower standard deviation of returns, which impacts on the relationship between the former two yardsticks which may be expressed as $\beta_{i}=\left(\rho_{i, m} x \sigma_{i}\right) / \sigma_{m}$ where $\rho_{i, m}$ denotes the correlation between asset $i$ and the market index $m$, and $\sigma$ denotes the standard deviation.

Note 3. A different scatter diagram which uses beta as a proxy for risk was plotted, and the insights were qualitatively similar to those of Figure 3. 


\section{Appendix 1}

List of sampled funds and market model coefficients

\begin{tabular}{|c|c|c|c|}
\hline \multicolumn{4}{|l|}{ Panel A: AIFs } \\
\hline Name of Fund & Intercept $(\alpha)$ & Slope & $\mathrm{R}^{2}$ \\
\hline Diamond Global Opportunities D1 & -0.0011 & $0.4342 * * *$ & 0.6800 \\
\hline Diamond Global Opportunities D2 EUR & -0.0016 & $0.4487 * * *$ & 0.7508 \\
\hline Diamond Growth B1 & 0.0001 & $0.3037 * * *$ & 0.5884 \\
\hline Diamond Neutral A1 & 0.0007 & $0.1799 * * *$ & 0.5234 \\
\hline Diamond Neutral A2 & 0.0004 & $0.1806 * * *$ & 0.5147 \\
\hline Diamond Neutral A3 & 0.0008 & $0.1799 * * *$ & 0.5168 \\
\hline Diamond Neutral AQ1 & 0.0007 & $0.1801 * * *$ & 0.5240 \\
\hline Diamond Neutral AQ2 & 0.0004 & $0.1797 * * *$ & 0.5118 \\
\hline Diamond Neutral AQ3 & 0.0008 & $0.1808 * * *$ & 0.5194 \\
\hline PvB (CH) Andante Fund - EM Portfolio K09L (USD) & -0.0011 & $0.4850 * * *$ & 0.2430 \\
\hline PvB (CH) Andante Fund - Global SP K (EUR) & -0.0015 & $0.3407 * * *$ & 0.6417 \\
\hline PvB (CH) Andante Fund - Global SP K (USD) & -0.0010 & $0.3383 * * *$ & 0.6515 \\
\hline PvB (CH) Andante Fund - Global SP K09L (EUR) & -0.0016 & $0.3392 * * *$ & 0.6434 \\
\hline PvB (CH) Andante Fund - Global SP K09L (USD) & -0.0002 & $0.3673 * * *$ & 0.4931 \\
\hline \multicolumn{4}{|l|}{ Panel B: UCITS } \\
\hline Name of Fund & Intercept $(\alpha)$ & Slope & $\mathrm{R}^{2}$ \\
\hline AL Trust Global Invest & 0.0035 & $0.5027 * * *$ & 0.3280 \\
\hline Apollo Styrian Global Equity A & 0.0039 & $0.6093 * * *$ & 0.4439 \\
\hline AXA Framlington Global Opportunities R Acc & 0.0031 & $0.7494 * * *$ & 0.5843 \\
\hline CFIC CRUX Global A Acc & 0.0043 & $0.6058 * * *$ & 0.5034 \\
\hline FT Global Dynamik & 0.0044 & $0.5336 * * *$ & 0.3851 \\
\hline Henderson Global Care Growth A Inc & 0.0035 & $0.6742 * * *$ & 0.5238 \\
\hline KBC Index World Cap & $0.0058 * *$ & $0.5291 * * *$ & 0.4639 \\
\hline Mutuafondo Bolsa A, FI & -0.0023 & $0.9816 * * *$ & 0.7067 \\
\hline Neptune Global Equity A Acc GBP & -0.0009 & $0.8134 * * *$ & 0.5741 \\
\hline Ohman Global Sustainable Brands & $0.0064 *$ & $0.3960 * * *$ & 0.2094 \\
\hline Quality Mejores Ideas, FI & 0.0039 & $0.4751 * * *$ & 0.3367 \\
\hline Scottish Widows Global Select Growth A Acc & 0.0023 & $0.6369 * * *$ & 0.4646 \\
\hline SEB Global Equity Multimanager B & 0.0038 & $0.5874 * * *$ & 0.4655 \\
\hline Sparinvest Value Aktier KL & 0.0015 & $0.7023 * * *$ & 0.5485 \\
\hline Stefnir - International Equities - EUR & 0.0026 & $0.5952 * * *$ & 0.5004 \\
\hline Tury Global Equity A & 0.0013 & $0.8509 * * *$ & 0.6422 \\
\hline
\end{tabular}

Note. The appendix shows the coefficients and explanatory power of the market models for the sampled funds, where the fund returns are regressed over an intercept (alpha) and the returns of the MSCI World TR USD Index. Statistical significance at the 99\%, 95\%, and 90\% levels of confidence is denoted by ***,**, and * respectively.

\section{Copyrights}

Copyright for this article is retained by the author(s), with first publication rights granted to the journal.

This is an open-access article distributed under the terms and conditions of the Creative Commons Attribution license (http://creativecommons.org/licenses/by/4.0/). 